\title{
Impact of DDD and VVIR Stimulation Modes on Functional Capacity and Quality of Life of Chagasic Patients
}

\author{
Impacto dos Modos de Estimulação DDD e VVIR na Capacidade Funcional e \\ Qualidade de Vida de Pacientes Chagásicos
}

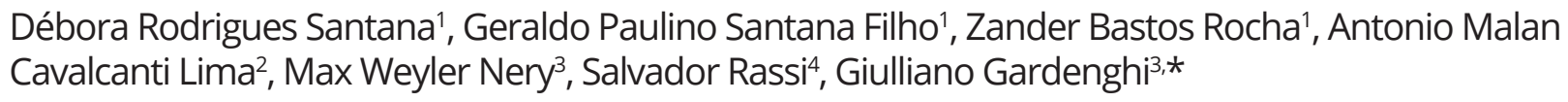

ORCID IDs

Santana DR (D) https://orcid.org/0000-0003-0659-8755

Nery MW (D) https://orcid.org/0000-0002-2944-6220

Santana Filho GP (D) https://orcid.org/0000-0002-3224-4435

Rassi S (iD https://orcid.org/0000-0001-7210-6486

Rocha ZB (D) https://orcid.org/0000-0002-1413-753X

Gardenghi G (iD https://orcid.org/0000-0002-8763-561X

Lima AMC (D) https://orcid.org/0000-0002-7252-9056

\begin{abstract}
Introduction: Atrioventricular stimulation provides hemodynamic benefits over the isolated ventricular rate, but this advantage is not completely established in chagasic patients with systolic dysfunction. Objectives: To evaluate the influence of DDD and VVIR stimulation modes on functional capacity, quality of life (QoL) and laboratory abnormalities of a natriuretic peptide in chagasic patients with ventricular dysfunction submitted to pacemaker implantation. Methods: Twenty patients ( $55 \%$ male) with a mean age of 62.7 ( \pm 9.9 years) and a mean ejection fraction of $41.8 \%$ $( \pm 2.8)$ were prospectively studied. Alternately, patients received pacing in the DDD and VVIR modes for a period of three months under each schedule. The minimum percentage of ventricular pacing was $80 \%$. After each period, the patient was submitted to the six-minute walk test (6MWT), QOL assessment by the Minnesota Living with Heart Failure Questionnaire (MLHFQ) and the Assay of QUAlity of life and RELated events (AQUAREL). Laboratory evaluation was performed with the $\mathrm{N}$-terminal fraction of the brain natriuretic peptide ( $\mathrm{N}$-terminal pro b-type natriuretic peptide - NT-proBNP). Results: The mean distance walked on the 6MWT in the DDD and VVIR modes were $390.60( \pm 52.71)$ and $396.30( \pm 52.71)$ meters respectively $(p=0.160)$. Results of lower QOL were found, considering the physical domain of the MLHFQ $(p=0.03)$ and the domains of effort dyspnea $(p=0.05)$ and arrhythmia $(p<0.001)$ of the AQUAREL with the WIR mode. NT-proBNP levels increased significantly with stimulation in VVIR mode $(p<0.001)$. Conclusion: After three months of stimulation with the VVIR mode, there was worsening of the QoL of the chagasic patients and increase of the levels of NT-proBNP (clinical trial record: ReBEc RBR-53×476)
\end{abstract}

\section{RESUMO}

Introdução: A estimulação atrioventricular propicia benefícios hemodinâmicos em relação à ventricular isolada, mas essa vantagem não está completamente estabelecida em pacientes chagásicos com disfunção sistólica. Objetivo: Avaliar a influência dos modos de estimulação DDD e WIR na capacidade funcional, qualidade de vida (QV) e alterações laboratoriais de peptídeo natriurético em pacientes chagásicos com disfunção ventricular submetidos a implante de marcapasso. Métodos: Estudaram-se prospectivamente 20 pacientes (55\% do sexo masculino) com média de idade de 62,7 ( $\pm 9,9$ anos) e média da fração de ejeção de 41,8\% ( $\pm 2,8)$. Alternadamente, os pacientes receberam a estimulação nos modos DDD e VVIR por um período de três meses sob cada programação. O mínimo percentual de estimulação ventricular admitido foi de $80 \%$. Após cada período, o paciente foi submetido ao teste de caminhada de seis minutos (TC6M), avaliação de QV pelo Minnesota Living with Heart Failure Questionnaire (MLHFQ) e pelo Assesment of QUAlity of life and RELated events (AQUAREL). A avaliação laboratorial foi realizada com a dosagem da fração N-terminal do peptídeo natriurético cerebral (N-terminal pro b-type natriuretic peptide - NT-proBNP). Resultados: A média da distância percorrida no TC6M nos modos DDD e WIR foram respectivamente 390,60 ( \pm 52,71) e 396,30 ( \pm 52,71) metros $(p=0,160)$. Verificaram-se resultados de QV inferiores, considerando o domínio físico do MLHFQ ( $p=0,03)$ e os domínios dispneia de esforço $(p=0,05)$ e arritmia $(p<0,001)$ do AQUAREL, com o modo WIR. Os níveis de NT-proBNP aumentaram significativamente com a estimulação no modo WIR ( $p<0,001)$. Conclusão: Após três meses de estimulação com o modo VVIR, houve piora da QV dos pacientes chagásicos e aumento dos níveis de NT-proBNP (registro de ensaio clínico: ReBEc RBR-53×476).

PALAVRAS-CHAVE: Doença de Chagas; Marcapasso; Qualidade de vida.

KEYWORDS: Chagas disease; Pacemaker; Quality of life.

1.Santa Casa de Misericórdia de Goiânia - Goiânia/GO - Brazil.

2.Pontifícia Universidade de Goiás - Goiânia/GO - Brazil.

3. Hospital ENCORE - Aparecida de Goiânia/GO - Brazil.

4. Universidade Federal de Goiás - Hospital das Clínicas - Serviço de Cardiologia - Goiânia/GO - Brazil.

*Correspondence author: ggardenghi@encore.com.br

Received: 03 Jul 2018 | Accepted: 04 Feb 2019

Section Editor: J. Tarcísio Medeiros de Vasconcelos 


\section{INTRODUCTION}

Despite the decline in the number of new cases of Chagas disease (CHD), its endemic condition and chronicity sustain it as an important health problem in South America ${ }^{1}$. Recent data show that 20 to $30 \%$ of the millions of HIV positive people manifest, every year, some form of cardiomyopathy ${ }^{2,3}$. The involvement of the cardiac excito-conductive system by Trypanosoma cruzi remains the second most frequently involved etiology in conventional pacemaker implantation in $\mathrm{Brazi}^{4}$. The important reduction of mortality in this population consecrated the artificial stimulation as a treatment of choice of bradycardia ${ }^{5}$.

The structural and electronic evolution of pacemakers aroused interest in detecting additional benefits such as quality of life (QoL). Atrioventricular (AV) pacing has been shown to be superior to unicameral pacing, which has therefore been deferred if sinus activity is present $t^{6}$. However, the evidence for $\mathrm{QoL}$ and functional capacity are based on populations without CHD and with preserved ejection fraction. Little information correlates the results of QOL and functional capacity with the use of specific tools for chagasic patients with pacemakers.

\section{OBJECTIVE}

To assess the effects of artificial cardiac pacing modes on QOL and functional capacity of chagasic patients with total AV block undergoing pacemaker implantation and to detect their influence on the levels of the N-terminal fraction of the cerebral natriuretic peptide ( $\mathrm{N}$-terminal pro b-type natriuretic peptide - NT-proBNP).

\section{METHODS}

This is a prospective, controlled clinical study performed in Santa Casa de Misericórdia de Goiânia (SCMG), state of Goiás, in patients submitted to doublechamber pacemaker implantation, from July 2014 to April 2015. After the approval of the study by the SCMG Ethics Committee (CAAE: 32745114.4.0000.5081), patients were evaluated at the return visit that occurs, on average, 10 days post-pacemaker implant.

Included in the inclusion criteria were: serological confirmation of $\mathrm{CHD}$, verification of total AV block by electrocardiogram or Holter prior to implantation, and left ventricular ejection fraction of less than $50 \%$ by the Simpson method. The detection of atrial fibrillation at any time of follow-up, clinically important chronic obstructive pulmonary disease, coronary artery disease (with prior diagnosis or angina pectoris), presence of ambulation limiting condition, cardiac insufficiency functional class (FC) IV of the New York Heart Association (NYHA) and artificial ventricular pacing of less than $80 \%$ were considered exclusion criteria.

Eligible patients were allocated in chronological order of the implant in groups A or B to avoid the learning effect in the evaluations. The participants of group A had their mode of stimulation initially programmed in DDD and those of group B in VVIR mode. After 90 days, they were submitted to the first evaluation that consisted of the application of the QOL questionnaires; six-minute walk test (6MWT); and blood sample collection for NT-proBNP dosing. Afterward, the patients were reprogrammed to the other mode of stimulation, according to the group to which they belonged. After 90 days, the second evaluation was performed and the patients were referred to the pacemaker outpatient clinic for the final decision of the assistant team regarding the definitive pacing mode.

The $6 \mathrm{MWT}$ was used as a functional evaluation instrument and performed according to the recommendations of the American Thoracic Society $(\mathrm{ATS})^{7}$. Two questionnaires were applied in both planned assessments: the Minnesota Living with Heart Failure Questionnaire (MLHFQ) and the Assay of QUAlity of life and RELated events (AQUAREL).

The MLHFQ was used in the transcultural version published and validated in Portuguese, which encompasses the emotional and physical domains in 21 questions that, together, result in the total score in which larger values correspond to the better aspect of $\mathrm{QoL}^{8}$. The AQUAREL questionnaire consists of 20 questions directly linked to aspects relevant to patients with pacemakers, distributed in three domains: chest discomfort; effort dyspnea; and arrhythmia. NT-proBNP was measured by the $\mathrm{Cardiac}^{\circledR}$ NT-proBNP $\left(\right.$ Roche $\left.^{\circledR}\right)$ test. 
In the VVIR mode, the programmed frequency was $60 \mathrm{bpm}$ and, since the patients had advanced degree AV block, there was no AV synchronization at any time. The devices of the ADAPTA-ADDR03 model (Medtronic Inc., Minneapolis, USA) had a sensor of the type accelerometer and pacemakers ENTOVIS DR-T (Biotronik SE \& Co, Berlin, Germany) operated with a closed-loop sensor. For both sensors, the minimum frequency of 60 and a maximum of $130 \mathrm{bpm}$ was established.

In DDD mode, the minimum pacing rate was $50 \mathrm{bpm}$ and the maximum frequency was $80 \%$ of the maximum for age. The established upper track rate was $130 \mathrm{bpm}$.

The AV interval was not individualized, being maintained the nominal of $120 \mathrm{~ms}$ after a spontaneous «p» wave and $150 \mathrm{~ms}$ after a stimulated «p» wave. The occurrence of a dynamic AV interval was allowed.

\section{Statistical analysis}

The verification of normality of the quantitative data was performed with the Kolmogorov-Smirnov test. Parametric variables were analyzed by paired t-test. The Wilcoxon test was applied for non-parametric variables. Regarding the frequencies found in the NYHA classification, the chi-square hoc-post-test was used, as described by Beasley et al. ${ }^{9}$. For all analyses, a significance level of $5 \%(\mathrm{p}<0.05)$ was adopted with a 95\% confidence interval from a convenience sample. The Spearman test was used to evaluate the correlation between QOL results, functional capacity, and NT proBNP dosages.

\section{RESULTS}

After applying the inclusion criteria, 23 patients were selected for the study. Three of these did not complete the follow-up because they presented atrial fibrillation or less than $80 \%$ of ventricular pacing (Fig. 1).

Twenty patients aged $38-75$ years, mean age of $62.7( \pm 9.9)$ years, of which nine $(45.5 \%)$ were female, completed the study protocol (Table 1$)$. The mean ejection fraction was $41.80 \%( \pm 2.50)$. The prevalence of arterial hypertension found in the sample was 30\% and the application of the binomial test demonstrated that the use of antihypertensive drugs did not change significantly in the different phases of the evaluation.

At random, $50 \%$ of the patients selected from the final sample had received ADAPTA ADDR03 pacemaker/ basic frequency 50-60 bpm. The other half received pacemakers from the ENTOVIS DR-T model.

The distance walked by patients in the 6MWT ranged from 210 to $525 \mathrm{~m}$, with a mean of $390.60( \pm 54.73)$ in ventricular pacing (VVIR). In the DDD mode, it ranged from 375 to $650 \mathrm{~m}$, with a mean of $396.30( \pm 52.71)$. There was no significant difference between the means of distance walked in the two modes of stimulation. The mean heart rate at the end of the 6MWT in DDD modes $88.60( \pm 4.66)$ and VVIR $90.50( \pm 4.57)$ were not significantly different. The change in pacing mode did not affect NYHA CF (Table 2).

Data on QOL evaluations from MLHFQ scores revealed a worsening of the aspects considered in the physical domain, being $13.35( \pm 3.50)$ in DDD mode and 14.60 ( \pm 3.78$)$ in VVIR mode. The emotional dimension of this questionnaire did not have a significant influence on the stimulation mode, with a mean score ranging from $8.45( \pm 4.10)$ DDD to $8.80( \pm 4.30)$ in VVIR mode, as seen in Table 3.

The AQUAREL results indicated that the stimulation mode did not affect the chest discomfort domain, whose mean was $85.78( \pm 10.51)$ in DDD mode and 84.80 $( \pm 10.73)$ in VVIR mode. However, in the effort dyspnea domain, there was a worsening of the mean of 76.23 $( \pm 11.92)$ in DDD mode to $70.88( \pm 11.60)$ in VVIR mode. Similarly, in the arrhythmia domain, the mean obtained ranged from $79.77( \pm 8.82)$ in DDD mode to $62.75( \pm 12.92)$ in VVIR mode, as shown in Table 3. The mean NT- proBNP, while the patients were under DDD pacing, was $372.81( \pm 81.42)$ and $495.30( \pm 105.4)$ under VVIR stimulation, as shown in Fig. 2.

In the DDD mode, the Spearman test indicated a correlation between the results found in the physical and emotional domains of the MLHFQ with its total score. In addition, it was possible to verify a correlation between the effort dyspnea and arrhythmia domain analysis of the AQUAREL questionnaire, with the results of the MLHFQ in DDD mode (Fig. 3) and in the VVIR mode (Fig. 4). 


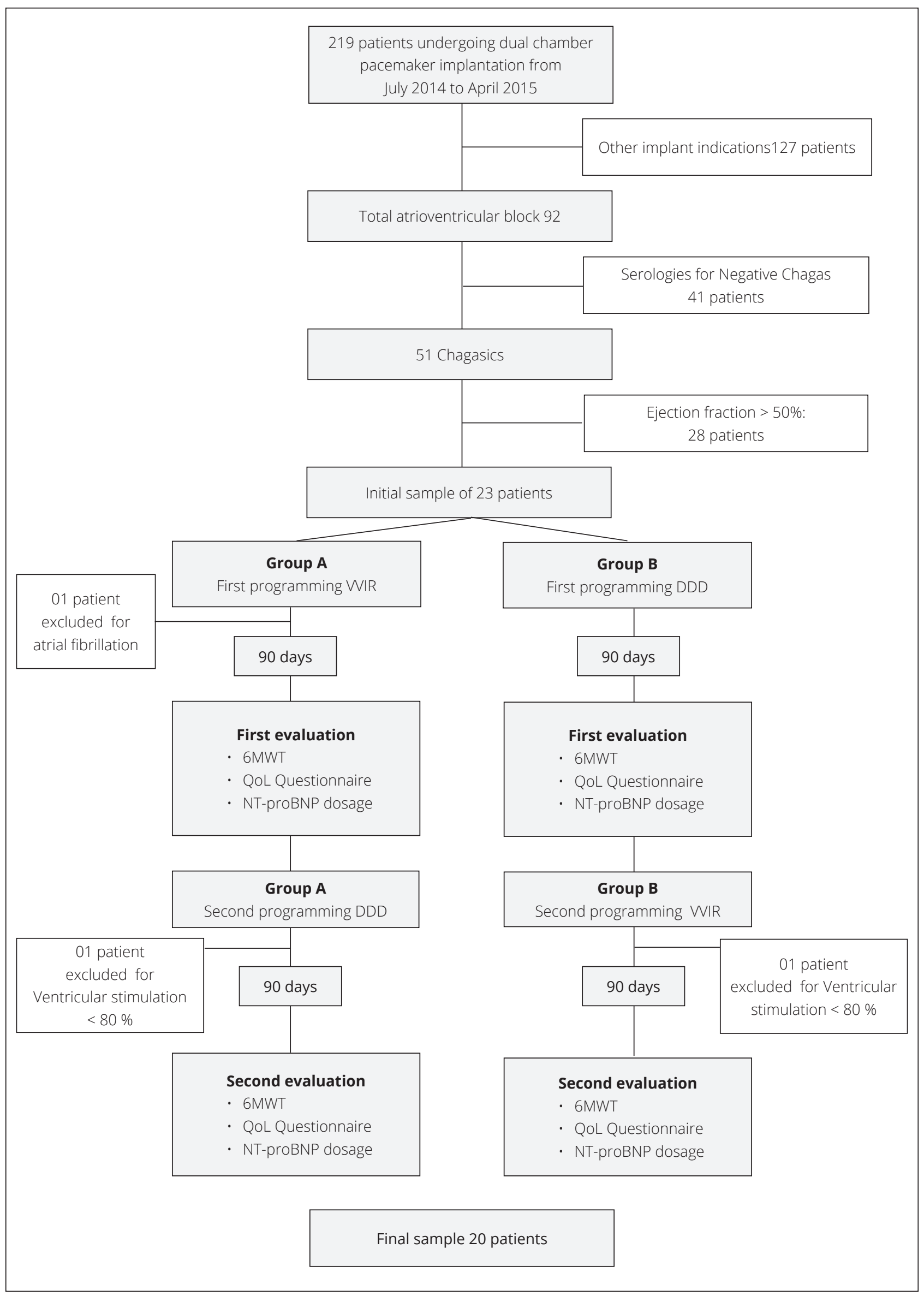

Figure 1. Study design. 
Table 1. Characteristics of the patients studied.

\begin{tabular}{|c|c|c|c|c|c|c|}
\hline Patient & Gender & Age & EF Simpson (\%) & NYHA DDD & NYHA VVIR & Group \\
\hline 1 & $\mathrm{~F}$ & 64 & 42 & 1 & II & $A$ \\
\hline 2 & M & 60 & 40 & II & I & $A$ \\
\hline 3 & M & 60 & 45 & II & I & $A$ \\
\hline 4 & $\mathrm{~F}$ & 47 & 40 & II & ॥ & $\mathrm{B}$ \\
\hline 5 & $\mathrm{~F}$ & 56 & 44 & I & 1 & $\mathrm{~B}$ \\
\hline 6 & $\mathrm{~F}$ & 53 & 40 & II & II & $\mathrm{B}$ \\
\hline 7 & $\mathrm{~F}$ & 69 & 44 & III & ॥ & $A$ \\
\hline 8 & M & 38 & 44 & II & II & B \\
\hline 9 & M & 72 & 42 & I & II & $B$ \\
\hline 10 & $M$ & 74 & 43 & I & ॥ & A \\
\hline 11 & M & 56 & 40 & II & II & B \\
\hline 12 & M & 56 & 40 & II & II & $A$ \\
\hline 13 & $\mathrm{~F}$ & 75 & 46 & II & III & B \\
\hline 14 & $F$ & 71 & 46 & II & II & B \\
\hline 15 & $\mathrm{M}$ & 59 & 40 & II & II & $A$ \\
\hline 16 & $M$ & 75 & 39 & III & II & B \\
\hline 17 & $\mathrm{M}$ & 72 & 43 & II & II & B \\
\hline 18 & $\mathrm{M}$ & 62 & 42 & II & II & $A$ \\
\hline 19 & $\mathrm{~F}$ & 69 & 38 & II & II & $A$ \\
\hline 20 & $\mathrm{~F}$ & 65 & 38 & II & II & $A$ \\
\hline
\end{tabular}

EF Simpson (\%) = left ventricular ejection fraction; NYHA DDD = functional class (CF) of New York Heart Association after 90 days of stimulation under the atrioventricular mode; NYHA WVIR = FC from the New York Heart Association after 90 days of stimulation under the mode of ventricular pacing with sensordetermined frequency response and inhibition by paced ventricular electrical event.

Table 2. Post-hoc chi-square test scores comparing New York Heart Association (NYHA) frequencies between DDD and VVIR.

\begin{tabular}{|c|c|c|c|}
\hline \multirow{2}{*}{ Classification NYHA } & \multicolumn{2}{|c|}{ Group n (\%) } & \multirow{2}{*}{ p-value* } \\
\hline & DDD & VVIR & \\
\hline I & $4(20.0)$ & $3(15.0)$ & 0.68 \\
\hline II & $14(70.0)$ & $16(80.0)$ & 0.47 \\
\hline III & $2(10.0)$ & $1(5.0)$ & 0.55 \\
\hline
\end{tabular}

DDD = atrioventricular stimulation; NYHA = functional class of the New York Heart Association; VIR = ventricular pacing mode with sensor-determined frequency response and inhibition by ventricular electrical event sensed by the pacemaker; * = chi-square post hoc.

Table 3. Comparison of the Minnesota Living with Heart Failure Questionnaire (MLHFQ) domains between DDD and VVIR modes.

\begin{tabular}{lccc}
\hline \multirow{2}{*}{ Minnesota Living with Heart Failure Questionnaire } & \multicolumn{2}{c}{ Média \pm desvio padrão } & \multirow{2}{*}{ p-value* } \\
\cline { 2 - 3 } Emotional & DDD & $8.80 \pm 4.30$ & 0.51 \\
Physic & $8.45 \pm 4.10$ & $14.60 \pm 3.78$ & 0.03 \\
Total & $13.35 \pm 3.50$ & $33.15 \pm 5.89$ & 0.73 \\
\hline Assesment of QUAlity of life and RELated events & $33.75 \pm 7.30$ & VVIR & p-value* \\
\hline Chest discomfort & DDD & $84.80 \pm 10.73$ & 0.14 \\
Dyspnoea of effort & $76.78 \pm 10.51$ & $70.88 \pm 11.60$ & 0.005 \\
Arrhythmia & $79.77 \pm 8.82$ & $62.75 \pm 12.92$ & $<0.001$ \\
\hline
\end{tabular}

*Wilcoxon test. 


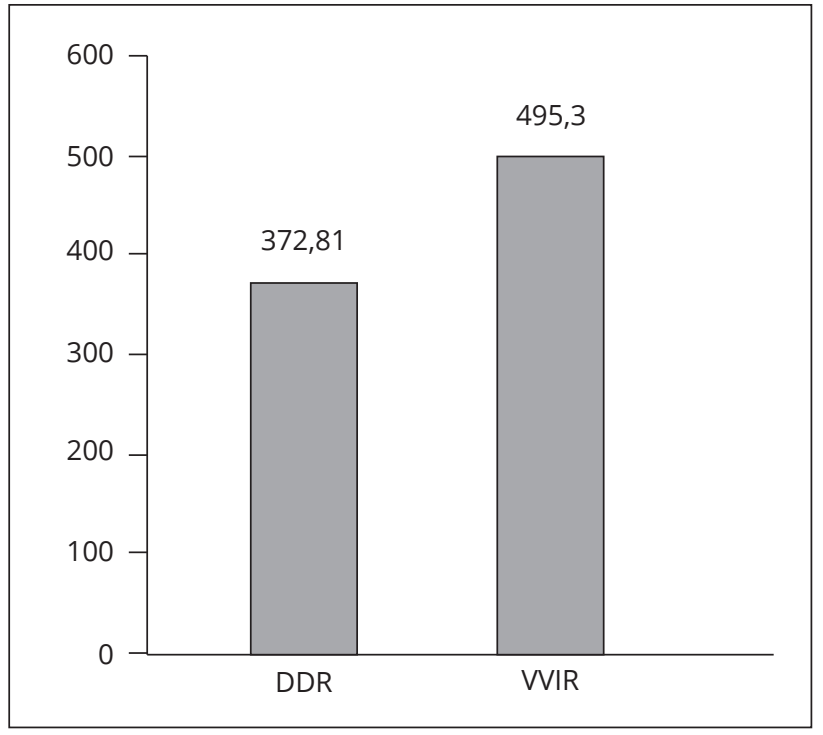

Figure 2. Serum levels of the $\mathrm{N}$-terminal fraction of the brain natriuretic peptide ( $\mathrm{N}$-terminal pro b-type natriuretic peptide) in the DDD and VVIR modes (95\% confidence interval).

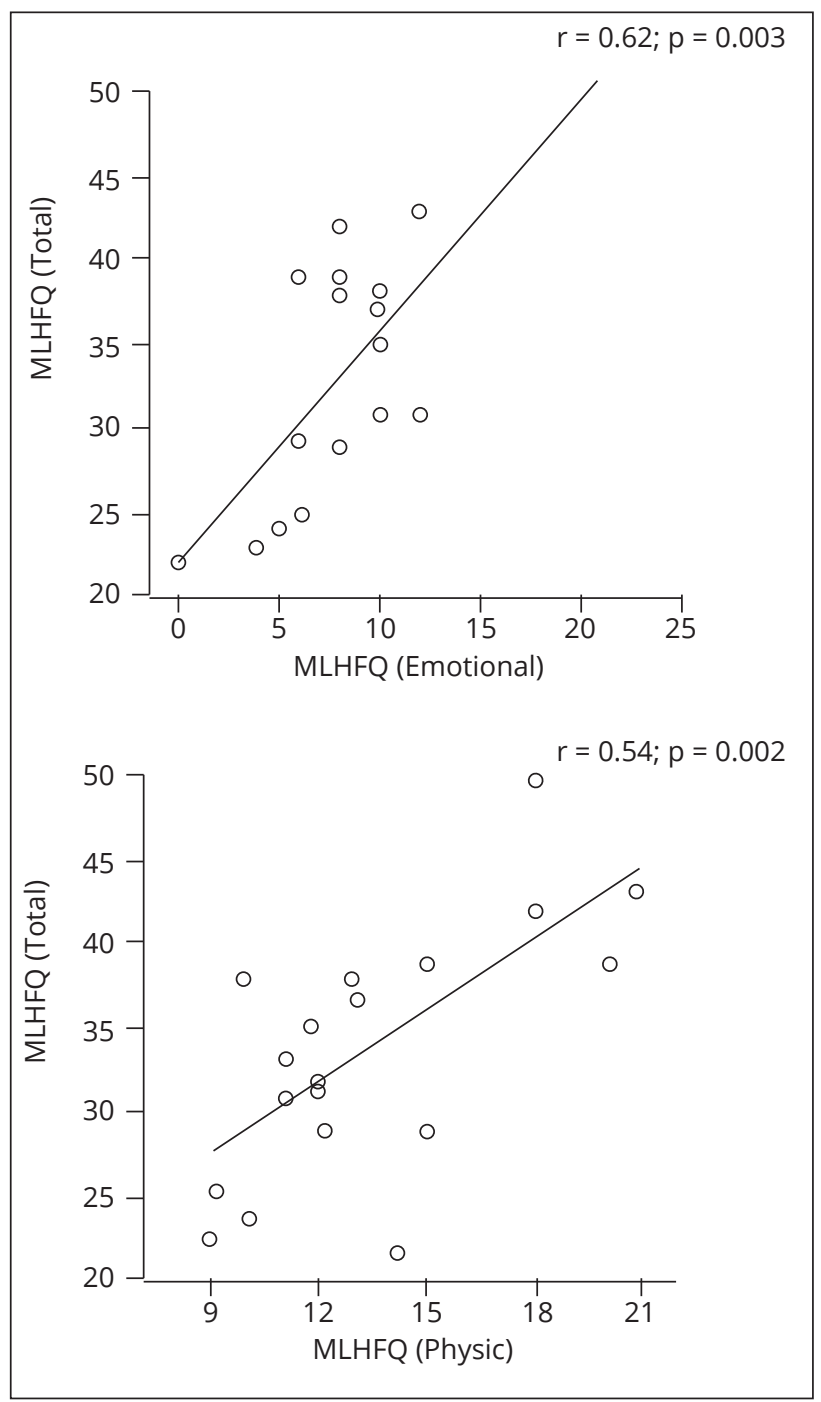

Figure 3. Scatter plot showing Spearmanıs correlation between the quality of life variables in DDD mode.

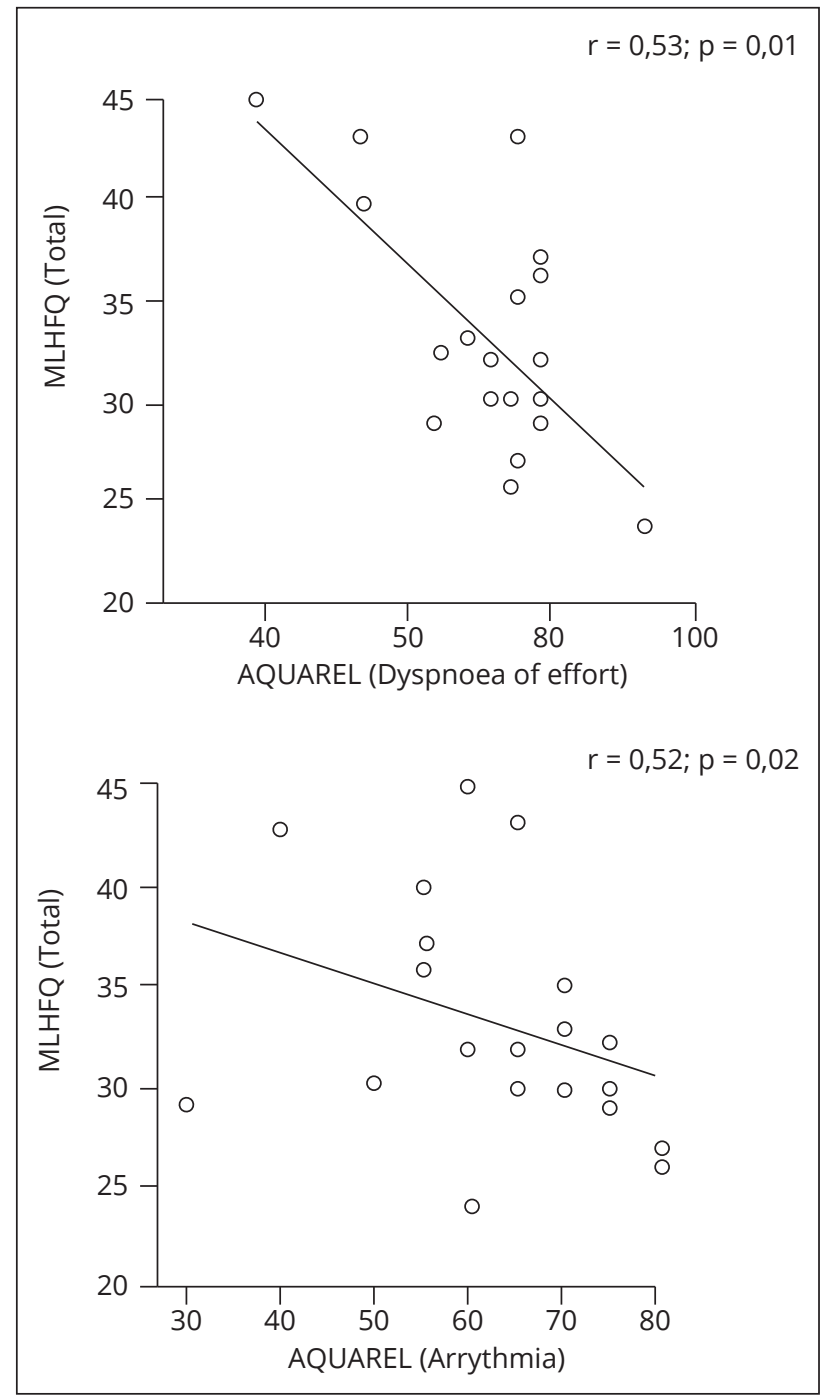

Figure 4. Scatter plot showing the results of the Spearman correlation between quality of life variables in VVIR mode.

\section{DISCUSSION}

The results of this work demonstrate that the AV stimulation mode provides a better impact on QoL according to both instruments used.

Although no significant effect on the global MLHFQ score, when analyzing its physical component, we noticed that the DDD stimulation presented higher results $(p=0.03)$. The MLHFQ is an instrument with well-defined accuracy for patients with ventricular dysfunction ${ }^{10}$, including chagasic cardiomyopathy ${ }^{8}$. This questionnaire was also used to detect repercussions of artificial stimulation on QOL, as in Santos et al. ${ }^{11}$, in which they analyzed the influence of the sensor activity in patients under DDD stimulation mode. 
The responses obtained by AQUAREL, which encompassed the domains effort dyspnea $(p=0.005)$ and arrhythmia $(\mathrm{p}<0.001)$, showed a better perception of QOL under DDD stimulation mode. In the sample from this study, the worst scores were detected in the arrhythmia domain. This finding is consistent with the study by Oliveira et $\mathrm{al}^{12}$, in which low means in the AQUAREL questionnaire were characteristic of chagasic patients, in addition to being associated with worse stages of heart failure, according to CF. On the other hand, Barros et al. ${ }^{13}$ measured the QOL of a population of elderly without CHD with AQUAREL application and observed that the worst measures were concentrated in the effort dyspnea domain. These considerations highlight the role of the arrhythmogenic manifestation characteristic of $\mathrm{ChD}$ and the magnitude of its reflex in the perception of the QoL of these individuals.

Therefore, it is important to use specific instruments to evaluate QoL in chagasic patients under artificial stimulation. The use of the SF-36, an overall assessment instrument, did not detect differences in QOL under the effects of VVIR or DDD/R stimulation in elderly patients in a randomized clinical trial ${ }^{14}$. Teno et al ${ }^{15}$ selected chagasic patients at the time of the change of the pacemaker generator and concluded that there were no differences in QV between the DDD or VVIR modes according to the SF-36. It is important to use global and specific instruments to evaluate health interventions. There is evidence that the values of SF- 36 scores change significantly in the first few months after pacemaker implantation, while the results of AQUAREL can be perceived over the course of five years ${ }^{16}$.

In the present study, although the evaluation of the functional capacity by the 6MWT did not show that the AV stimulation provided better performance than the unicameral $(p=0.16)$, its values correlated with the QoL assessments by both MLHFQ $(r=0.62$, $\mathrm{p}=0.003)$ and AQUAREL $(\mathrm{r}=0.44, \mathrm{p}=0.04)$ in VVIR mode. With these results, it was found that patients with worse functional capacity also had worse QoL scores.

In a randomized double-blind study with nonchagasic participants, 17 there was no change in functional capacity for 6MWT with changes in pacing modes. Sá et al. ${ }^{18}$ found that, after eight months of pacemaker implantation, there was worsening of the results obtained in the $6 \mathrm{MWT}$ in relation to the first month after the implant. Therefore, although the 6MWT is considered a submaximal test that triggers global and integrated responses of the systems involved during exercise, it is not able to show differences related to ventricular or AV pacing modes ${ }^{15}$.

The dosage of natriuretic peptides to detect early progression of ventricular dysfunction has gained prominence in recent years ${ }^{19}$. Ventricular pacing may cause early elevation of NT-proBNP levels independently of echocardiographic abnormality ${ }^{20}$. In the study by Souza et al. ${ }^{21}$, the brain natriuretic peptide (BNP) was measured at the sixth month and one year after the implantation of the pacemaker. These authors found a significant increase of BNP in the second dose when the left ventricular ejection fraction showed no difference in relation to the initial measurement ${ }^{21}$.

The selection criteria used in this study allowed the formation of a homogeneous sample with ventricular dysfunction to the pacemaker implant. The VVIR pacing mode was found to have resulted in a significant elevation of NT-proBNP levels. This elevation may be related to AV dyssynchrony or worsening mitral regurgitation secondary to right apical stimulation. In the analysis of this study, the ventricular pacing site was not discriminated, but it is known that its short-term effects are not completely elucidated ${ }^{22}$.

The only variable with which the high levels of NT-proBNP correlated in the sample of this study was the distance covered in the 6MWT in VVIR mode, suggesting the close relationship of the functional capacity with the serum elevation of this peptide.

These data refer to a follow-up of 90 days in a sample consisting of 20 patients. This makes the observation not conclusive, but capable of giving important information about the type of cardiac stimulation in the patient with Chagas cardiomyopathy.

\section{CONCLUSION}

The DDD mode provides better QoL for chagasic patients with ventricular dysfunction without affecting their functional capacity measured by the 6MWT. The VVIR pacing mode resulted in elevated serum NT-proBNP levels after three months of follow-up. 


\section{AUTHORS' CONTRIBUTION}

\author{
Conceptualization, Santana DR and Rassi S;
} Methodology, Santana DR; Lima AMC and Rassi S; Research, Santana DR; Santana Filho GP and Rocha ZB;
Writing - First version, Santana DR and Rassi S; Writing

- Review \& Edition, Santana DR; Rassi S; Nery MW and

Gardenghi G; Resources, Santana DR; Supervision, Rassi S.

\section{REFERENCES}

1. Rassi AJ, Rassi A, Marin-Neto J. Chagas disease. Lancet. 2010;375(9723):1388-402. https://doi.org/10.1016/S01406736(10)60061-X

2. World Health Organization. Chagas disease in Latin America: an epidemiological update based on 2010 estimates. Weekly Epidemiol Rec. 2015;90(6):33-43.

3. Sabino EC, Ribeiro AL, Salemi VMC, Di Lorenzo Oliveira C, Antunes AP, Menezes MM, et al. Ten-year incidence of Chagas cardiomyopathy among asymptomatic Trypanosoma cruzi seropositive former blood donors. Circulation. 2013;127(10):1105-15. https://doi.org/10.1161/ circulationaha.112.123612

4. Pachon JC, Pereira W, Batista Junior WD, Pachón JPM, Pachón CEI, Vargas RNA, et al. RBM - Registro Brasileiro de Marcapassos, Ressincronizadores e Desfibriladores. Relampa. 2013;26(1):39-49.

5. Rassi A, Rassi Jr A, Faria GHDC. História natural do bloqueio atrioventricular total de etiologia chagásica. Arq Bras Cardiol. 1992;59(Suppl II):191.

6. Martinelli Filho M, Zimerman LI. Diretrizes brasileiras de dispositivos cardíacos eletrônicos implantáveis (DCEI). Arq Bras Cardiol. 2007;89(6):e210-38.

7. American Thoracic Association. ATS statement: guidelines for the six-minute walking test. Am J Resp Critical Care Med. 2002;166(1):111-7. https://doi.org/10.1164/ ajrccm.166.1.at1102

8. Carvalho VO, Guimarães GV, Carrara D, Bacal F, Bocchi EA. Validação da versão em português do Minnesota Living with Heart Failure Questionnaire. Arq Bras Cardiol. 2009;93:3944. https://doi.org/ 10.1590/S0066-782X2009000700008

9. Beasley TM, Schumacker RE. Multiple regression approach to analyzing contingency tables: post hoc and planned comparison procedures. J Exp Educ. 1995;64(1):79-93. https://doi.org/10.1080/00220973.1995.9943797

10. Rector TS, Kubo SH, Cohn JN. Validity of the Minnesota Living with Heart Failure Questionnaire as a measure of therapeutic response to enalapril or placebo. Am J Cardiol. 1993;71(12):1106-7.

11. Santos JRC. Marcapassos dupla-câmara com resposta de frequência melhoram a qualidade de vida dos pacientes? Relampa. 2002;15(4):201-5.

12. Oliveira BG, Abreu MNS, Abreu CDG, Rocha MOC, Ribeiro AL. Health-related quality of life in patients with Chagas disease. Rev Soc Bras Med Trop. 2011;44:150-6. https://doi. org/10.1590/S0037-86822011005000002

13. Barros RTD, Carvalho SMRD, Silva MAM, Borges JBC. Avaliação de aspectos da qualidade de vida em pacientes pós-implante de marcapasso cardíaco. Rev Bras Cir
Cardiovasc. 2014:37-44. https://doi.org/10.5935/16789741.20140009

14. Lamas GA, Orav EJ, Stambler BS, Ellenbogen KA, Sgarbossa EB, Huang SKS, et al. Quality of life and clinical outcomes in elderly patients treated with ventricular pacing as compared with dual-chamber pacing. NEJM. 1998;338(16):1097-104. https://doi.org/10.1056/NEJM199804163381602

15. Teno LAC, Costa R, Martinelli Filho M, Castilho FCT, Ruiz I. Mudança do modo WI para DDD ("upgrade") na troca eletiva do gerador de pulsos: análise comparativa clínicofuncional. Arq Bras Cardiol. 2007;88(2):128-33. https://doi. org/10.1590/S0066-782X2007000200001

16. Udo EO, van Hemel NM, Zuithoff NP, Nijboer $H$, Taks W, Doevendans PA, et al. Long term quality-of-life in patients with bradycardia pacemaker implantation. Inter J Cardiol. 2013;168(3):2159-63. https://doi.org/10.1016/j. ijcard.2013.01.253

17. Ouali S, Neffeti E, Ghoul K, Hammas S, Kacem S, Gribaa R, et al. DDD versus WIR pacing in patients, ages 70 and over, with complete heart block. Pacing Clin Electrophysiol. 2010;33(5):5839. https://doi.org/10.1111/j.1540-8159.2009.02636.x

18. Sá LAB, Rassi S, Batista MAL. Efeitos da estimulação ventricular convencional em pacientes com função ventricular normal. Arq Bras Cardiol. 2009;93:167-73. https://doi.org/10.1590/S0066-782X2009000800016

19. Porapakkham P, Porapakkham P, Zimmet H, Billah B, Krum H. B-type natriuretic peptide-guided heart failure therapy: a meta-analysis. Arch Intern Med. 2010;170(6):507-14. https:// doi.org/10.1001/archinternmed.2010.35

20. Naegeli B, Kurz DJ, Koller D, Straumann E, Furrer M, Maurer $D$, et al. Single-chamber ventricular pacing increases markers of left ventricular dysfunction compared with dual-chamber pacing. Europace. 2007;9(3):194-9. https://doi.org/10.1093/ europace/eul186

21. Souza SF, Nascimento B, Nunes MCP, da Silva JLP, Carvalho $V T$, Beaton $A Z$, et al. Effect of pacemaker site on B-type natriuretic peptide levels, and left ventricular function in a population with high prevalence of Chagas disease. Inter J Cardiol. 2015;190:315-8. https://doi.org/10.1016/j. ijcard.2015.04.127

22. Nikoo MH, Ghaedian MM, Kafi M, Fakhrpour A, Jorat $M V$, Pakfetrat $M$, et al. Effects of right ventricular septal versus apical pacing on plasma natriuretic peptide levels. J Cardiovasc Dis Res. 2011;2(2):104-9. https://doi. org/10.4103\%2F0975-3583.83036 